\title{
COVID-19: the difference between the nose and the lung
}

\author{
Matteo Gelardi ${ }^{1}$, Mario Notargiacomo ${ }^{2}$, Eleonora Maria Consiglia Trecca ${ }^{1}$, Michele Cassano ${ }^{1}$, \\ Giorgio Ciprandi ${ }^{3}$
}

${ }^{1}$ Department of Otolaryngology, University of Foggia; ${ }^{2}$ Otorhinolaryngology Unit, Melzo Hospital, Milan; ${ }^{3}$ Allergy Clinic, Casa di Cura Villa Montallegro, Genoa, Italy

To the Editor

An elegant study reported dysmorphic cells and syncytia in the deceased's lungs for COVID-19 [1]. The authors reasonably considered that most of these syncytia-forming cells were pneumocytes, as identified by specific biomarkers. However, cellular dysmorphism and syncytia are pathological features common in other respiratory infections caused by different viruses, including the human respiratory syncytial virus (HRSV) and Epstein-Barr virus (EBV), as correctly documented $[2,3]$.

On the other hand, a respiratory infection due to viruses, including rhinovirus, adenovirus, myxovirus, and coronavirus, usually results in ciliocytophthoria of nasal ciliated cells [4]. The term ciliocytophthoria identifies characteristic cytological alterations, including rarefaction/disappearance of ciliary apparatus, a confluence of cytoplasmatic vacuoles, "decapitation" of the apical portion of the ciliated cell. In this regard, a recent report demonstrated that nasal and bronchial epithelial cells, recovered from a patient with severe COVID-19, displayed only partial rarefaction of the cilia, the presence of some binucleated cells, and the reduction/disappearance of the hyperchromatic stria [5]. These mild cytopathic alterations were consistent with the nose and bronchi's mild involvement in asymptomatic or paucisymptomatic COVID19 patients (Figure 1).

The possible explanation of this gianic behavior does not depend on ACE-2 receptor expression, well represented along the whole respiratory tract. Instead, the composition of the epithelial lining seems to have a pathogenic role. Namely, the epithelium's height and complexity gradually decrease along the respiratory tract, from the tall pseudostratified ciliated columnar cells inter-

Correspondence: Giorgio Ciprandi, Allergy Clinic, Casa di Cura Villa Montallegro, Genoa, Italy.

E-mail gio.cip@libero.it

Key words: COVID-19; nose; bronchi; lung; epithelial cell.

Received for publication: 30 November 2020.

Accepted for publication: 14 January 2021.

${ }^{\circ}$ Copyright: the Author(s), 2021

Licensee PAGEPress, Italy

Monaldi Archives for Chest Disease 2021; 91:1708

doi: 10.4081/monaldi.2021.1708

This article is distributed under the terms of the Creative Commons Attribution Noncommercial License (by-nc 4.0) which permits any noncommercial use, distribution, and reproduction in any medium, provided the original author(s) and source are credited.
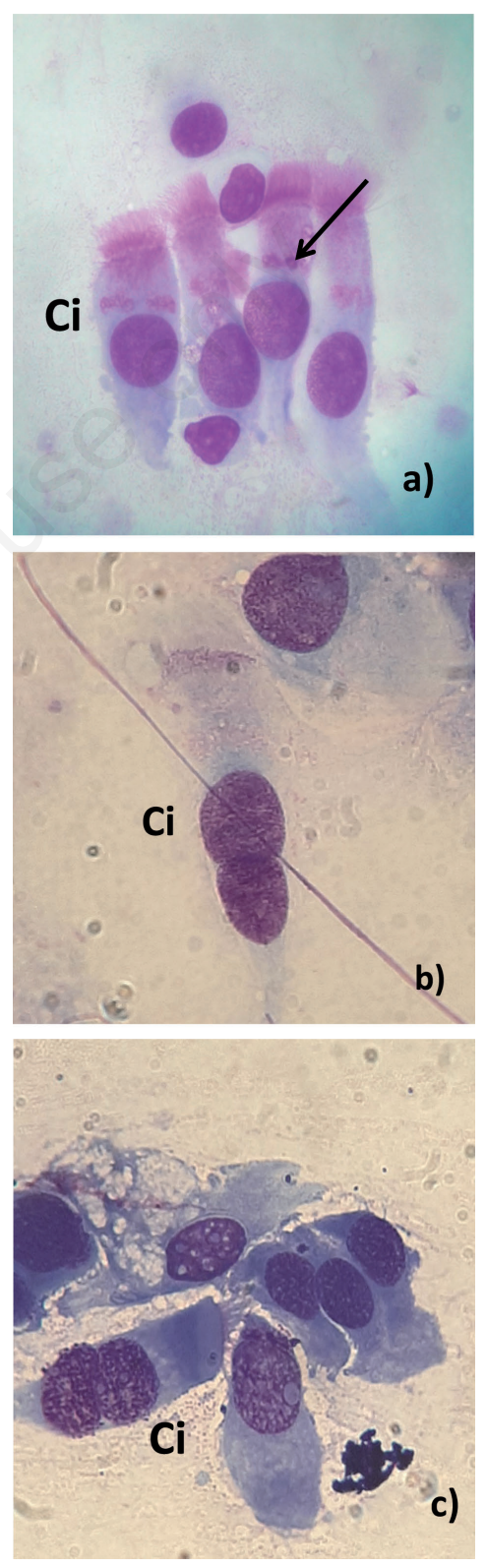

Figure 1. a) Normal nasal cytology; Ci, ciliated cell, the arrow shows the hyperchromatic supranuclear stria (May Grunwald Giemsa, 800x magnification). b) Nasal cytology in COVID-19 patient; $\mathrm{Ci}$, binucleated ciliated cells, absence of the hyperchromatic supranuclear stria (May Grunwald Giemsa, 1000x magnification). c) Bronchial cytology in COVID-19 patient reveals the absence of the hyperchromatic supranuclear stria (May Grunwald Giemsa, 800x magnification). 
spersed with goblet cells to the thin pneumocytes. Therefore, pneumocytes can be more easily attacked than nasal cells by SARSCoV-2.

\section{References}

1. Bussani R, Schneider E, Zentilin L, et al. Persistence of viral RNA, pneumocyte syncytia and thrombosis are hallmarks of advanced COVID-19 pathology. EBioMedicine 2020;61: 103104 .
2. Gagliardi TB, Ferreira Criado M, Proenca-Modena JL, et al. Syncytia induction by clinical isolates of human respiratory syncytial virus A. Intervirology 2017;60:56-60.

3. Gelardi M, Tomaiuolo M, Cassano M, et al. Epstein-Barr virus induced cellular changes in nasal mucosa. Virology J 2006;3:6.

4. Gelardi M, Ciprandi G. Ciliocytophthoria of nasal epithelial cells after viral infection: a sign of suffering cell. Acta Biomed 2019;90:7-9.

5. Gelardi M, Notargiacomo $M$, Trecca EMC, Cassano $M$. SARS-CoV-2: Naso-bronchial cytological correlations. Am J Otolaryngol 2020;41:102549. 